\title{
NOVOZAVJETNA BIBLIJSKA BIBLIOGRAFIJA (2016.-2018.)
}

\author{
Karlo Višaticki - Tihonija Zovko
}

Sveučilište J. J. Strossmayera u Osijeku Katolički bogoslovni fakultet u Đakovu karlo.visaticki@djkbf.hr
UDK: 27-242(01)=163.42“2016/2018“ https://doi.org/10.34075/cs.55.2.9 Stručni rad Rad zaprimljen 2/2020.

\section{Sažetak}

Prilogje drugi dio, nastavak priloga, koji je već objavljen u „Crkvi u svijetu“, a koji se odnosi na starozavjetni dio biblijske bibliografije na hrvatskom jeziku. Obradeno je ukupno sedamnaest (17) časopisa, koji su publicirani u Republici Hrvatskoj odnosno u Bosni i Hercegovini. Prilog je podijeljen u sedam (7) dijelova: 1. Izdanja Svetog pisma (1 x); 2. šest (6) monografija; 3. dvije (2) doktorske disertacije; 4. ostalo: jedan (1) spis; 5. dvadeset devet (29) priloga u zbornicima od osamnaest (18) autora; 6. prilozi iz stručnih časopisa znanstvenog karaktera (A1, A2...) - ukupno trideset sedam (37) priloga od dvadeset četiri (24) autora, te 7. prilozi iz „tjednika, mjesečnika, Biblija danas" - ukupno sto šesnaest priloga (116) od jedanaest (11) autora. Želja je i nakana autora priloga biti od pomoći svim kolegicama $i$ kolegama ali i svim studenticama/ studentima te ljubiteljima Riječi Božje, koji se bave Biblijom i kojima ovaj prilog može olakšati traženje naslova određene tematike.

Ključne riječi: Biblija, Novi zavjet, Biblijska bibliografija, hrvatska biblijska bibliografija, novozavjetna hrvatska biblijska bibliografija

\section{UvOD}

Bibliografske jedinice izdvojene su iz časopisa publiciranih $\mathrm{u}$ Hrvatskoj i Bosni i Hercegovini: Biblija danas, Bogoslovska smotra, Bosna franciscana, Crkva na kamenu, Crkva u svijetu, Diacovensia, Hercegovina franciscana, Kairos, Nova prisutnost, Katolički tjednik, Lađa, Riječki teološki časopis, Služba Božja, Svjetlo riječi, Vjesnik Đakovačko-osječke nadbiskupije i Srijemske biskupije, Vrhbosnensia, Živo vrelo 


\section{SVETO PISMO}

- Evanđelje po Luki / priredila M. Admirata Lučić; [ s grčkog preveo Mario Cifrak], Sarajevo, Provincija Bezgrješnoga začeća BDM, Družbe sestara Služavki Maloga Isusa, 2017.

\section{MONOGRAFIJE:}

- BABIĆ, Nada, Hrvatski prijevodi Novoga zavjeta od 20. stoljeća, Kršćanska sadašnjost, Zagreb, 2018.

- CIFRAK, Mario, I riječ je Božja rasla : od kerigme do evanđelja, KS, Zagreb, 2016.

- ČATIĆ, Ivica, Crkva novo društvo usred staroga imperija: obrisi Pavlove političke teologije, Glas Koncila, Zagreb, 2016.

- SCHNACKENBURG, Rudolf, Evanđelje po Marku, Glas Koncila, 2018. (Sv.1, Sv.2)

- DUGANDŽIĆ, Ivan, Poslanica Rimljanima, KS, Zagreb, 2018.

- ZOVKIĆ, Mato, Isusove parabole - slike o kraljevstvu Božjem, Katolički bogoslovni fakultet, Sarajevo; Glas Koncila, Zagreb, 2018.

\section{DOKTORSKE DIZERTACIJE:}

- $\quad$ KRASICKI, Arkadiusz, Rođenje iz vode i Duha (usp. Iv 3,3-8) egzegeza i učinci kod F. Porscha i F. Libermanna: doktorski rad, Vlas. naklada, Zagreb, Katolički bogoslovni fakultet, 2017.

- MALY, Anđelo, Dall'atleta incatenato al campione celeste: eschatologia e metafora agnostica nella Lettera ai Filippesi, Bologna, Edizioni Dehoniane, 2017.

\section{Ostalo}

- ZOVKIĆ, Mato, Pedeset godina moga teološkog pisanja:(1967.2017.), Medijski centar Vrhbosanske nadbiskupije, Sarajevo, 2018.

\section{PRILOZI U ZBORNICIMA}

- BARŠČEVSKI, Taras, Demografsko pitanje i Novi zavjet, u: Poslovna etika i demografska politika,[uredio Ivan Koprek], FTI, Zagreb, 2017., 135-155. 
- $\quad$ CIFRAK, Mario, Kršćansko iskustvo Boga. Motiv Isusova sustolništva, u: Znat će da prorok bijaše među njima (Ez 33,33). Zbornik u čast prof. dr. sc. Bože Lujića, OFM, povodom 70. godine Života, [uredili Stipo Kljajić, Mario Cifrak], KS, Zagreb, 2018., 343-358.

- ČATIĆ, Ivica, Novozavjetna Pasha i oslobođenje čovjeka, u: Znat će da prorok bijaše među njima (Ez 33,33). Zbornik u čast prof. dr. sc. Bože Lujića, OFM, povodom 70. godine života, [uredili Stipo Kljajić, Mario Cifrak], KS, Zagreb, 2018., 359-394.

- DUGANDŽIĆ, Ivan, „ГNONTE $\Sigma$ TON $\Theta E O N . . . “($ Rim 1,21): (ne) mogućnost prirodne spoznaje Boga kod Pavla?, u: Znat će da prorok bijaše među njima (Ez 33,33). Zbornik u čast prof. dr. sc. Bože Lujića, OFM, povodom 70. godine života, [uredili Stipo Kljajić, Mario Cifrak], KS, Zagreb, 2018., 413-435.

- DUGANDŽIĆ, Ivan, Blažena Djevica Marija u Novome zavjetu, s posebnim osvrtom na Ivanovo Evanđelje i knjigu, Otkrivenja, u: Gospi Tekijskoj. Zbornik radova s Međunarodnoga znanstvenog simpozija prigodom 300. obljetnice svetišta Gospe Tekijske održanog 20. i 21. svibnja 2016. u Petrovaradinu, [uredili Darija Damjanović Barišić, Ivica Raguž, Boris Vulić], Katolički bogoslovni fakultet, Đakovo, 2017., 41-62.

- DUGANDŽIĆ, Ivan, Pavao i Izrael. Apostol pogana između evanđelja i izabranog naroda, u: Bogu - gospodaru i ljubitelju života (Mudr 11,26). Zbornik u čast prof. dr. sc. Nikole Hohnjeca povodom 70. godine života, [uredili Božo Lujić, Darko Tepert], KS, Zagreb, 2016., 309-327.

- FUŽINATO, s. Silvana, Misericordia e giudizio in Gv 9, u: I vangeli della misericordia ( a cura di Giulio Michelini), Ancora, Milano, 2016., 85-108.

- FUŽINATO, s. Silvana, „Milosrđe mi je milo, a ne žrtva“ (Mt 9, 13), u: Koprek, Ivan (ur.), Ima li u ekonomiji mjesta za milosrđe?, FTI, Zagreb, 2016., 93.-122.

- $\quad$ FUŽINATO, s. Silvana, Evo, ja vas šaljem kao ovce među vukove. Poziv i poslanje učenika u Mt 10, u: Šporčić, Ivan (ur.), Poziv, poslanje i služenje. Pedeset godina svećeništva Tomislava Šporčića, Gospićko-senjska biskupija, Gospić, 2017., 349.-366.

- FUŽINATO, s. Silvana, La Misera e la Misericordia. Dinamiche pragmatiche in Gv 8,1-11, u: Guidi, Maurizio - Zeni, Stefano (ur.), Numeri Secondi. Il volto di Dio attraverso il volto dei piccoli. Scritti in onore del prof. don Massimo Grilli in occasione del suo $70^{\circ}$ compleanno, GBP, Roma, 2018., str. 325-338. 
- JURIČ, Stipe, „Blago onome koji čita i onima koji slušaju riječi ovoga proroštva“ (Otk 1,3), u: Bogu-gospodaru i ljubitelju života (Mudr 11,26). Zbornik u čast prof. dr. sc. Nikole Hohnjeca povodom 70. godine života, [uredili Božo Lujić, Darko Tepert], KS, Zagreb, 2016., 329-341.

- KOMADINA, Ante, Isusov križ. Simbol ljubavi i spasonosna trpljenja, u: Ecce homo! Medicinski i teološki pristupi. Zbornik radova znanstvenog skupa, Split, 16. ožujka 2018.,[uredio Ante Mateljan], CuS, Split, 2018., 53-70.

- KOSCIS, Imre, „Selig, ihr Armen“(Lk 6,20)- „Selig die Armen im Geist" (Mt 5.3. Erwägungen zu den Seligpreisungen im Lukasevangelium und im Matthäusevangelium, u: Znat će da prorok bijaše među njima (Ez 33,33). Zbornik u čast prof. dr. sc. Bože Lujića, OFM, povodom 70. godine života, [uredili Stipo Kljajić, Mario Cifrak], KS, Zagreb, 2018., 297-306.

- KOSCIS, Imre, Der auferstandene Christus als Vermittler und Spender des Lebens in 1 Kor 15, u: Bogu-gospodaru i ljubitelju života (Mudr 11,26). Zbornik u čast prof. dr. sc. Nikole Hohnjeca povodom 70. godine života, [uredili Božo Lujić, Darko Tepert], KS, Zagreb, 2016., 229-242.

- MALY, Anđelo / BOŠNJAKOVIĆ, Josip, „Zarobljeno milosrđe“. Biblijsko-psihološka analiza Fil 2, 1-4, u: O Božjem milosrđu: zbornik radova s Međunarodnoga znanstvenog simpozija o milosrđu održanog 22. travnja 2016. godine na Katoličkom bogoslovnom fakultetu u Đakovu Sveučilišta Josipa Jurja Strossmayera u Osijeku, [uredili Ivica Raguž, Šimo Šokčević], Katolički bogoslovni fakultet, Đakovo, 2016., 37-56.

- PARLOV, Mladen, Majčinstvo: Teološko-duhovni pogled, u: Ecce homo! Medicinski i teološki pristupi. Zbornik radova znanstvenog skupa, Split, 16. ožujka 2018.,[uredio Ante Mateljan], CuS, Split, 2018.,99-108.

- PEHAR, Marija, Božja utjeha - utjeha Bogom, u: Ecce homo! Medicinski i teološki pristupi. Zbornik radova znanstvenog skupa, Split, 16. ožujka 2018.,[uredio Ante Mateljan], CuS, Split, 2018., 185-294.

- $\quad$ SCHMATOVICH, Janos, Die Lehre von der Versöhnung bei dem heiligen Paulus. Gottestat in Christus, u: Znat ce da prorok bijaše među njima (Ez 33,33). Zbornik u čast prof. dr. sc. Bože Lujića, OFM, povodom 70. godine života, [uredili Stipo Kljajić, Mario Cifrak], KS, Zagreb, 2018., 437-453.

- $\quad$ TOMAŠEVIĆ, Darko, Aktualnosti Novozavjetne egzegeze i teologije. Djelomičan izbor i pregled novozavjetne literature na teme- 
lju časopisa New Testament Abstracts za 2012. godinu, u: Bogu - gospodaru i ljubitelju života (Mudr 11,26). Zbornik u čast prof. dr. sc. Nikole Hohnjeca povodom 70. godine života, [uredili Božo Lujić, Darko Tepert], KS, Zagreb, 2016., 437-460.

- TOMAŠEVIĆ, Darko, Fil 2, 5-11, u: Znat će da prorok bijaše među njima (Ez 33,33). Zbornik u čast prof. dr. sc. Bože Lujića, OFM, povodom 70. godine života, [uredili Stipo Kljajić, Mario Cifrak], KS, Zagreb, 2018., 395-412.

- TOMAŠEVIĆ, Darko, Uskrsnuće: mit ili pak realnost? Vrhunac spasenja i zalog vječnog života, u: Ecce homo! Medicinski i teološki pristupi. Zbornik radova znanstvenog skupa, Split, 16. ožujka 2018.,[uredio Ante Mateljan], CuS, Split, 2018., 342-361.

- VIDOVIĆ, Marinko, Logion otvrdnuća (Iz 6,9s) u razumijevanju odnosa Crkve ižidovstua, u: Znat će da prorok bijaše među njima (Ez 33,33). Zbornik u čast prof. dr. sc. Bože Lujića, OFM, povodom 70. godine života, [uredili Stipo Kljajić, Mario Cifrak], KS, Zagreb, 2018., 455-486.

- VIDOVIĆ, Marinko, Pavlovo poimanje stvorenja i kozmičke dimenzije spasenja (Rim 8,19-22), u: Bogu-gospodaru i ljubitelju života (Mudr 11,26). Zbornik u čast prof. dr. sc. Nikole Hohnjeca povodom 70. godine života, [uredili Božo Lujić, Darko Tepert], KS, Zagreb, 2016., 183-227.

- VIDOVIĆ, Pero, Istovjetnost Božjih i Isusovih samoobjava: JaJesam u Otkrivenju, u: Bogu-gospodaru i ljubitelju života (Mudr 11,26). Zbornik u čast prof. dr. sc. Nikole Hohnjeca povodom 70. godine života, [uredili Božo Lujić, Darko Tepert], KS, Zagreb, 2016., 243-264.

- VIDOVIĆ, Pero, Stari zavjet se u Novom otkriva. Dva primjera u Markovu evanđelju, u: Znat će da prorok bijaše među njima (Ez 33,33). Zbornik u čast prof. dr. sc. Bože Lujića, OFM, povodom 70. godine života, [uredili Stipo Kljajić, Mario Cifrak], KS, Zagreb, 2018., 277-296.

- VUGDELIJA, Marijan, Knjiga zapečaćena sa sedam pečata $i$ Jaganjac (Otk 5,1-14), u: Znat će da prorok bijaše među njima (Ez 33,33). Zbornik u čast prof. dr. sc. Bože Lujića, OFM, povodom 70. godine života, [uredili Stipo Kljajić, Mario Cifrak], KS, Zagreb, 2018., 487-534.

- ZOVKIĆ, Mato, Prorok Ilija u Novom zavjetu - uzor vjernicima $i$ nadahnuće Isusu, u: Prorok Ilija. Zbornik radova o sv. Iliji u povodu 10. obljetnice Samostana - duhovnog centra Karmel sv. Ilije 2006.-2016. [uredio Jure Zečević ], HIZ, Zagreb, 2016., 37-70. 
- ZOVKIĆ, Mato, Starozavjetni citati u Lukinu tumačenju muke Kristove, u: Bogu-gospodaru i ljubitelju života (Mudr 11,26). Zbornik u čast prof. dr. sc. Nikole Hohnjeca povodom 70. godine života, [uredili Božo Lujić, Darko Tepert], KS, Zagreb, 2016., 163-182.

- ZOVKIĆ, Mato, Vladavina Božja u parabolama iz Lukina evanđelja, u: Znat će da prorok bijaše među njima (Ez 33,33). Zbornik u čast prof. dr. sc. Bože Lujića, OFM, povodom 70. godine života, [uredili Stipo Kljajić, Mario Cifrak], KS, Zagreb, 2018., 307-341.

\section{PRILOZI IZ STRUČNIH ČASOPISA ZNANSTVENOG KARAKTERA (A1, A2...)}

- $\quad$ ARAČIĆ, Dinko, Marija, znak nade, u rimskoj liturgiji, u: Služba Božja 57 (2017) 3, 285-305.

- $\quad$ BAJIĆ, Monika, Živa Rijeka, u: Kairos 11 (2017) 1, 91-100.

- BALINT-FEUDVARSKI, Miroslav, Posvećenje kroz spoznaju $i$ oponašanje u Poslanici Filipljanima, u: Kairos 12 (2018) 1, 23-42.

- $\quad$ BARŠČEVSKI, Taras, Unutarcrkveni dijalog - izazov i put ostvarenja crkvenog zajedništva, u: Bogoslovska smotra 88 (2018) 3, 543-559.

- $\quad$ BERKOVIĆ, Danijel, Isus i Psalmi, u: Kairos 10 (2016) 1, 41-60.

- BUDISELIĆ, Ervin, Pouke iz rane Crkve za današnje evanđeosko kršćanstvo, u: Kairos 11 (2017) 1, 69.-90.

- BUDISELIĆ, Ervin, Glosolalija: zašto kršćani mogu na bogoslužju govoriti u jezicima bez tumačenja, u: Kairos 10 (2016) 2, 177-200.

- BUDISELIĆ, Ervin, Problematika izazova teologije „kraljeustvo sada" II. dio, u: Kairos 10 (2016) 1, 7-40.

- BUDISELIĆ, Ervin, Isus iz evanđelja i Isus danas, u: Kairos 12 (2018) 1, 7-21.

- CIFRAK, Mario, „Danas ćeš biti sa mnom u raju“ (Lk 23, 43), u: Bogoslovska smotra 87 (2017) 2, 377-390.

- CIFRAK, Mario, „Isus Krist danas istije i uvijeke“ (Heb 13,8), u: Lađa 11 (2017) 4, 2-9.

- CIFRAK, Mario, Perikopa o kamenu ugaonom i narodu Božjem kraljevskom svećenstvu u Prvoj Petrovoj poslanici (1 Pt 2, 4-10), u: Diacovensia 25 (2017) 1, 75-99. 
- $\quad$ ČATIĆ, Ivica - RAJIĆ, Marko, Retoričko-kritička analiza Poslanice Galaćanima (I), u: Diacovensia 25 (2017) 4, 567-583.

- ČATIĆ, Ivica - ANDELFINGER, Ivan, Isusov samopredstavljajuće-teofanijski "Ja sam" u Mk 6,50; Mt 14,27; Iv 6,20; 18, 5-6, u: Diacovensia 24 (2016) 1, 153-193.

- ČATIĆ, Ivica - RAJIĆ, Marko, Retoričko-kritička analiza Poslanice Galaćanima (II), u: Diacovensia 26 (2018) 1, 55-80.

- DUGANDŽIĆ, Ivan, Ivan Krstitelj. Prorok $i$ više od proroka, u: Hercegovina franciscana 13 (2017) 13, 49-58.

- DUGANDŽIĆ, Ivan, Marija u Novom zavjetu, s posebnim osvrtom na Iv i Otk, u: Hercegovina franciscana 12 (2016) 12, 47-69.

- $\quad$ FUŽINATO, s. Silvana, „Vidiš li ovu ženu” “. Pragmatička funkcija Lk 7, 36-50, u: Obnovljeni život 72 (2017) 1, 7-19.

- FUŽINATO, s. Silvana, „...Perché ha guardato la povertà della sua serva...", u: Presbyteri 4 (2017), 261.-270.

- FUŽINATO, s. Silvana, Povijest i kerigma u Mt 1-2, u: Riječki teološki časopis 25 (2017) 2 (50), 327-358.

- FUŽINATO, s. Silvana, Živjeti sadašnjost u svjetlu susreta sa Sinom Čovječjim: oblikovanje čitatelja u apokaliptičkom govoru Mt 24 - 25., u: Bogoslovska smotra 87 (2017) 2, 327-349.

- HAMP, Siniša, Stupovi uravnotežene mjesne crkve: Egzegetsko razmatranje 1. Solunjanima 5,12-22, u: Kairos 11 (2017) 2, 227-243.

- KRASICKI, Arkadiusz, Konačna pobjeda dobra nad zlom. Novo rođenje u Otk 12, u: Bogoslovska smotra 87 (2017) 2, 437-452.

- NEAGOE, Alexandru, Uspjeh kroz neuspjeh: Lukin paradoksalni pogled na kršćansko poslanje Židovima, u: Kairos 12 (2018) 2, 221-229.

- COCCO, Paolo, Marija, majka Gospodinova u ekumenskim dijalozima, u: Služba Božja 57 (2017) 4, 477-488.

- PARLOV, Mladen, Očinstvo - poziv i poslanje, u: Služba Božja 57 (2017) 3, 381-397.

- PETROVIĆ, Irena - MAGDA, Ksenija, Globalna kršćanska misija i pouratak Efrajima : neke egzegetske mogućnosti za tumačenje Rimljanima 11, 25-26, u: Nova prisutnost 16 (2018) 2, 297-312.

- $\quad$ STEPP, Perry L., Sukcesija u doba Novog zavjeta, u: Kairos 10 (2016) 2, 161-175.

- TEPERT, Darko, Biblijska promišljanja uz Izvanredni jubilej milosrđa, u: Lađa 10 (2016) 1, 8-14. 
- $\quad$ THELLMAN, Gregory S., Četiri stadija objave: Sjedinjenje Svetog pisma, Isusove Riječi i Duha - prosvijetljeno sjećanje u četvrtom evanđelju, u: Kairos 11 (2017) 2, 209-226.

- $\quad$ THELLMAN, Gregory S., Inkorporiranje Isusa i njegovih poslanika u tripartitni kanonski okvir (Lk 11,45-53), u: Kairos 11 (2017) 1, 7-27.

- TOMAŠEVIĆ, Darko, Egzegetska analiza i poruka 1 Iv 1,1-2,2), u: Vrhbosnensia 22 (2018) 1, 77-97.

- $\quad$ TOMAŠEVIĆ, Luka, Luka o eshatologiji (apokaliptici) s osvrtom na Lk 21, u: Bogoslovska smotra 87 (2017) 2, 351-375.

- VIDOVIĆ, Marinko, Pavlova uporaba športskog rječnika i metafora: ciljno usmjereno ljudsko / kršćansko djelovanje u: Crkva u svijetu 53 (2018) 3, 375-415.

- VIDOVIĆ, Marinko, 1 Sol 4, 13-18: eshatologija u formi apokaliptike, u: Bogoslovska smotra 87 (2017) 2, 391-416.

- VIŠATICKI, Karlo - ZOVKO, Tihonija, Novozavjetna biblijska bibliografija na hrvatskom jeziku (2011.-2015.), u: Crkva u svijetu 52 (2017) 2, 304-337.

- ZOVKIĆ, Mato, Križ Isusov u Novom zavjetu kao izraz prihvaćanja nasilne smrti, u: Vrhbosnensia 20 (2016) 1, 63-80.

\section{PRILOZI IZ TJEDNIKA, MJESEČNIKA, BibliJA DANAS}

- BARŠČEVSKI, Taras, Isus Krist - sin Davidov, u: Biblija danas 16(23)(2018)4, 16-21.

- BERNARDIĆ, Mario, Izgubljeni, ali ne za trajno, u: Katolički tjednik 15(39)(2016)14, 16-18.

- CRNČEVIĆ, Ante, Došašće - nadahnuće za proročki život vjere, u: Živo vrelo 33 (2016) 12, 8-15.

- $\quad$ CRNČEVIĆ, Ante, Izgubljeni i u Bogu pronađeni. Prispodobe o milosrđu u Evanđelju po Luki, u: Živo vrelo 33 (2016) 2, 1 - 10.

- $\quad$ CRNČEVIĆ, Ante, Punina vremena u Kristu. Vječnost-učiteljica života u vremenu, u: Živo vrelo 33 (2016) 13, 8 -15.

- CRNČEVIĆ, Ante, Otac milosrđa i Bog utjehe. Tješiti i opraštati po Božjem milosrđu, u: Živo vrelo 33 (2016) 5, 2 -6.

- CRNČEVIĆ, Ante, Veliča duša moja Gospodina. Hvalospjev Marijine duše, u: Živo vrelo 35 (2018) 12, 8-12.

- ČATIĆ, Ivica, Samoobjava Isusa kao Sina Božjega i sujedočanstva (Iv 5, 19-47), u: Vjesnik Đakovačko-osječke nadbiskupije i Srijemske biskupije 144 (2016) 9, 960-963. 
- $\quad$ ĆATIĆ, Ivica, Blagdan posvete Hrama-Isus je novi Hram (Iv 10, 22-42), u: Vjesnik Đakovačko-osječke nadbiskupije i Srijemske biskupije 145 (2017) 4, 431-433.

- ČATIĆ, Ivica, Blagdan sjenica: Isus obećava Duha Svetog ( Iv 7, 1-53), u: Vjesnik Đakovačko-osječke nadbiskupije i Srijemske biskupije 144 (2016) 12, 1335-1337.

- ČATIĆ, Ivica, Blagdan Sjenica: Isus-svjetlo svijeta, oprašta grijehe preljubnici (Iv 8, 1-59), u: Vjesnik Đakovačko-osječke nadbiskupije i Srijemske biskupije 145 (2017) 1, 79-81.

- ČATIĆ, Ivica, Isus i Hram (Iv 2, 13-25), u: Vjesnik Đakovačkoosječke nadbiskupije i Srijemske biskupije 144 (2016) 1, 75-76.

- Č́ATIĆ, Ivica, Susret s Nikodemom (Iv 3, 1-21), u: Vjesnik Đakovačko-osječke nadbiskupije i Srijemske biskupije 144 (2016) 2, 216-217.

- ČATIĆ, Ivica, Posljednje sujedočanstvo Ivana Krstitelja (Iv 3, 22-36), u: Vjesnik Đakovačko-osječke nadbiskupije i Srijemske biskupije 144 (2016) 3, 305-307.

- ČATIĆ, Ivica, Isus i Samarijanka (Iv 4, 1-42), u: Vjesnik Đakovačko-osječke nadbiskupije i Srijemske biskupije 144 (2016) 4, 434-436.

- $\quad$ ČATIĆ, Ivica, Drugo znamenje u Kani Galilejskoj (Iv 4, 43-54), u: Vjesnik Đakovačko-osječke nadbiskupije i Srijemske biskupije 144 (2016) 5, 572-574.

- ČATIĆ, Ivica, Ozdravljenje uzetoga i rasprava o subotnjem počinku (Iv 5, 1-18), u: Vjesnik Đakovačko-osječke nadbiskupije i Srijemske biskupije 144 (2016) 6, 699-701.

- ČATIĆ, Ivica, Znamenje umnažanja kruha (Iv 6, 1-21), u: Vjesnik Đakovačko-osječke nadbiskupije i Srijemske biskupije 144 (2016) 10, 1087-1088.

- $\quad$ ČATIĆ, Ivica, Isus - Kruh života (Iv 6, 22-71), u: Vjesnik Đakovačko-osječke nadbiskupije i Srijemske biskupije 144 (2016) 11, 1196-1198.

- ČATIĆ, Ivica, Isus ozdravlja slijepca od rođenja (Iv 9, 1-41), u: Vjesnik Đakovačko-osječke nadbiskupije i Srijemske biskupije 145 (2017) 2, 214-215.

- ČATIĆ, Ivica, Isus - dobri pastir (Iv 10, 1-21), u: Vjesnik Đakovačko-osječke nadbiskupije i Srijemske biskupije 145 (2017) 3, 314-316.

- ČATIĆ, Ivica, Isus uskrisuje Lazara (Iv 11), u: Vjesnik Đakovačko-osječke nadbiskupije i Srijemske biskupije 145 (2017) 5, 567-568. 
- ČATIĆ, Ivica, Pomazanje u Betaniji, mesijanski ulazak u Jeruzalem i završetak Isusova javnog djelovanja (Iv 12, 1-50), u: Vjesnik Đakovačko-osječke nadbiskupije i Srijemske biskupije 145 (2017) 6, 718-719.

- Č́ATIĆ, Ivica, Knjiga proslave (Iv 13,1-20,31), u: Vjesnik Đakovačko-osječke nadbiskupije i Srijemske biskupije 145 (2017) 9, 1015-1017.

- Č́ATIĆ, Ivica, Isus, Juda i Petar (Iv 13, 21-38), u: Vjesnik Đakovačko-osječke nadbiskupije i Srijemske biskupije 145 (2017) 10, 1155-1157.

- $\quad$ ČATIĆ, Ivica, Oproštajni govori (Iv 14-17), u: Vjesnik Đakovačko-osječke nadbiskupije i Srijemske biskupije 145 (2017) 11, 1297-1298.

- ČATIĆ, Ivica, Novi način prisutnosti Božje među ljudima-Duh Sveti (Iv 14, 15-31), u: Vjesnik Đakovačko-osječke nadbiskupije i Srijemske biskupije 145 (2017) 12, 1458-1460.

- ČATIĆ, Ivica, Otajstvo kraljevstva - prispodoba o sijaču (Mk 4,112), u: Biblija danas 15 (22) (2017) 3, 6-10.

- $\quad$ ČATIĆ, Ivica, Trs i loze-jedinstvo života Isusa i učenika (Iv 15, 117), u: Vjesnik Đakovačko-osječke nadbiskupije i Srijemske biskupije 146 (2018) 1, 80-82.

- $\quad$ ČATIĆ, Ivica, Usred mržnje svijeta učenici su sujedoci po Duhu (Iv 15, 18-16,4a), u: Vjesnik Đakovačko-osječke nadbiskupije i Srijemske biskupije 146 (2018) 2, 245-247.

- ČATIĆ, Ivica, Isusov odlazak, dar Duha i pobjeda nad svijetom (Iv 16,4b-33), u: Vjesnik Đakovačko-osječke nadbiskupije i Srijemske biskupije 146 (2018) 3, 400-402.

- ČATIĆ, Ivica, Isusova velikosvećenička molitva - I. (Iv 17, 1-8), u: Vjesnik Đakovačko-osječke nadbiskupije i Srijemske biskupije 146 (2018) 4, 532-534.

- Č́ATIĆ, Ivica, Isusova velikosvećenička molitva-II. (Iv 17, 9-19), u: Vjesnik Đakovačko-osječke nadbiskupije i Srijemske biskupije 146 (2018) 5, 673-675.

- C ČATIĆ, Ivica, Isusova velikosvećenička molitva-III (Iv 17, 20-26), u: Vjesnik Đakovačko-osječke nadbiskupije i Srijemske biskupije 146 (2018) 6, 808-809.

- $\quad$ ČATIĆ, Ivica, Uhićenje $i$ ispitivanje pred velikim svećenikom (Iv 18, 1-27), u: Vjesnik Đakovačko-osječke nadbiskupije i Srijemske biskupije 146 (2018) 9, 1063-1065. 
- ČATIĆ, Ivica, Sudski proces pred Pilatom (Iv 18,28-19,16a), u: Vjesnik Đakovačko-osječke nadbiskupije i Srijemske biskupije 146 (2018) 10, 1210-1212.

- ČATIĆ, Ivica, Raspeće (Iv 19, 16b-27), u: Vjesnik Đakovačko-osječke nadbiskupije i Srijemske biskupije 146 (2018) 11, 1364-1365.

- ČATIĆ, Ivica, Isusova smrt i ukop (Iv 19, 28-42), u: Vjesnik Đakovačko-osječke nadbiskupije i Srijemske biskupije 146 (2018) 12, 1507-1509.

- DANČUO, Milan, Hvalospjev starca Šimuna Sad otpuštaš. Evanđeoski hvalospjev u Povečerju, u: Živo vrelo 35 (2018) 12, 12-19.

- DUGANDŽIĆ, Ivan, 50 godina Biblije na hrvatskom jeziku, u: Hercegovina Franciscana 14 (2018) 14, 13-22.

- $\quad$ FUŽINATO, s. Silvana, Radost u Novim zavjetu. Dar i odgovornost kao konstitutivne značajke spasenjske radosti, u: Posvećeni život 20-21 (2015.-2016)37-38, 7-20.

- FUŽINATO, s. Silvana, Milosrđe $i$ sud (Iv 9), u: Posvećeni život 20-21 (2015.-2016) 37-38, 64-78.

- FUŽINATO, s. Silvana, Samarijanka- žena traženja (Iv 4,1-42), u: Biblija danas 16 (23) (2018) 1, 14-18.

- IVKOVIĆ, Željko (priredio), Povijest Betlehema kao naseljenog mjesta, u: Katolički tjednik 16 (40) (2017) 51-52, 30-31.

- LUJIĆ, Božo, Isusovo uskrsnuće. Konkretan dokaz kako hodati ovom zemljom, u: Svjetlo riječi 34 (2016) 397, 4-7.

- MALY, Anđelo, Oblikovanje crkvenog poslanja uz Krista Uskrslog. Biblijsko - teološka perspektiva, u: Živo vrelo 34 (2017) 4, $2-6$.

- MALY, Anđelo, Benedictus - himan Božjega pohoda jučer, danas i sutra, u: Živo vrelo 35 (2018) 12, 2-7.

- MURIĆ, Branko, „A kada dođe punina vremena, odasla Bog Sina svoga“(Gal 4,4), u: Živo vrelo 35 (2018) 13, 2-9.

- PARDON, Đurica, Novo čitanje i razumijevanje Isusovih prispodoba, u: Biblija danas 15 (22) (2017) 3, 3-5.

- POPOVIĆ, Anto, Uskrsnuće - mogućnost nemogućega, u: Svjetlo riječi 35 (2017) 409, 6-9.

- ŠSSSKO, Ivan, Tri prispodobe o nemilosrdnosti: pozivi na obraćenje u Svetoj godini milosrđa, u: Živo vrelo 33 (2016) 2, 11 -19.

- ŠAŠKO, Ivan, Milosrđe u djelima strpljivosti i ustrajnosti. Podnositi nevolje i moliti za žive i mrtve, u: Živo vrelo 33 (2016) 5, 7 -13. 
- $\quad$ ŠAŠKO, Ivan, Isus Krist u vjekovnome vremenu: in saecula saeculorum, u: Živo vrelo 33 (2016) 13, 2 - 7.

- $\quad$ TEPERT, Darko, Blago milosrdnima, u: Kana 47 (2016) 7-8 (511), 28-29.

- $\quad$ TEPERT, Darko, Ili mi ili oni?, u: Kana 48 (2017) 1 (516), 30-31.

- TEPERT, Darko, Izgubljene knjige u Novom zavjetu, u: Svjetlo riječi 35 (2017) 408, 13-15.

- TEPERT, Darko, Isusov grob i ukazanje anđela, u: Svjetlo riječi 35 (2017) 410, 11-13.

- $\quad$ TEPERT, Darko, Krist kao veliki svećenik, u: Svjetlo riječi 35 (2017) 411, 15-17.

- $\quad$ TEPERT, Darko, Kristovo milosrđe, u: Kana 47 (2016) 10 (513), 26-27.

- $\quad$ TEPERT, Darko, Kršćanski optimizam, u: Kana 48 (2017) 9 (523), 28-29.

- $\quad$ TEPERT, Darko, Milosrdni Isus suosjeća, u: Kana 47 (2016) 6 (510), 28-29.

- $\quad$ TEPERT, Darko, Milosrdni Samarijanac, u: Kana 47 (2016) 9 (512), 28-29.

- $\quad$ TEPERT, Darko, Milosrđe za kraj, u: Kana 47 (2016) 11 (514), 24-25.

- $\quad$ TEPERT, Darko, Misericordia et misera, u: Kana 47 (2016) 12 (515), 30-31.

- TEPERT, Darko, O caru i Bogu, u: Kana 48 (2017) 6 (521), 28-29.

- TEPERT, Darko, Prividna religioznost, u: Kana 48 (2017) 4 (519), 28-29.

- $\quad$ TEPERT, Darko, Tajna pogleda, u: Kana 48 (2017) 12 (526), 30-31.

- $\quad$ TEPERT, Darko, Uskrs u vrtu, u: Svjetlo riječi 35 (2017) 409, 13-15.

- $\quad$ TEPERT, Darko, Vjera nevjernika, u: Kana 48 (2017) 7-8 (522), 28-29.

- $\quad$ TEPERT, Darko, Vjera zajednice, u: Kana 48 (2017) 11 (525), 28-29.

- $\quad$ TEPERT, Darko, Vjerodostojnost riječi, u: Kana 48 (2017) 3 (518), 26-27.

- $\quad$ TOMAŠEVIĆ, Darko, Andrija i Šimun (Petar), u: Biblija danas 16 (23) (2018), 2; 15-19. 
- $\quad$ TOMAŠEVIĆ, Darko, Živi sujedoci Isusove muke. Mjesta Vazmenog trodnevlja, u: Katolički tjednik 15 (39) (2016) 12-13, 34-25.

- TOMAŠEVIĆ, Luka, Prispodoba o zrnu gorušičinu i kvascu (Mt 13,31-33), u: Biblija danas 15 (22) (2017) 3, 11-14.

- TURALIJA, Dubravko, „U punini vremena“ (Gal 4,4)- što to zapravo znači?, u: Katolički tjednik 16 (40) (2017) 51-52, 20-21.

- TURALIJA, Dubravko, Isus je uskrsnuo. Što to zapravo znači?, u: Katolički tjednik 16 (40) (2017) 15-16, 36-37.

- TURALIJA, Dubravko, Uskrs i Vazam, dva naziva istoga značenja, ali $i$ istoga korijena, u: Katolički tjednik 15 (39) (2016) 12-13, 20-21.

- ZOVKIĆ, Mato, Marija je s Isusom pjevala psalme kao vjerske pjesme Židova, u: Katolički tjednik 15 (39) (2016) 32-33, 30-33.

- ZOVKIĆ, Mato, Osobe Marijina zemaljskog putovanja, u: Katolički tjednik 16 (40) (2017) 32-33, 30-32.

- ZOVKIĆ, Mato, Parabola o gorušičinu zrnu i kvascu u tijestu (Prvi dio), u: Crkva na kamenu 38 (2017) 6 (439), 9-12.

- ZOVKIĆ, Mato, Parabola o gorušičinu zrnu i kvascu u tijestu (Drugi dio), u: Crkva na kamenu 38 (2017) 7 (440), 9-12.

- ZOVKIĆ, Mato, Parabola o dobrom vlasniku vinograda (Prvi dio), u: Crkva na kamenu 37 (2016) 5 (426), 9-12.

- ZOVKIĆ, Mato, Parabola o dobrom vlasniku vinograda (Drugi dio), u: Crkva na kamenu 37 (2016) 6 (427), 10-13.

- ZOVKIĆ, Mato, Parabola o domaćinu koji iz svoje riznice iznosi novo i staro, u: Crkva na kamenu 39 (2018) 5 (450), 9-12.

- ZOVKIĆ, Mato, Parabola o dužniku s oproštenjem golema duga kojije postao nemilosrdni vjerounik (Prvi dio), u: Crkva na kamenu 37 (2016) 3 (424), 9-12.

- ZOVKIĆ, Mato, Parabola o dužniku s oproštenjem golema duga koji je postao nemilosrdni vjerovnik ( Drugi dio), u: Crkva na kamenu 37 (2016) 4 (425), 9-12.

- ZOVKIĆ, Mato, Parabola o farizeju i porezniku (Prvi dio), u: Crkva na kamenu 39 (2018) 3 (448), 9-12.

- ZOVKIĆ, Mato, Parabola o farizeju i porezniku (Drugi dio), u: Crkva na kamenu 39 (2018) 4 (449), 9-12.

- ZOVKIĆ, Mato, Parabola o ljulju na njivi pšenice (Prvi dio), u: Crkva na kamenu 38(2017)10(443), 9-12.

- ZOVKIĆ, Mato, Parabola o ljulju na njivi pšenice (Drugi dio), u: Crkva na kamenu 38(2017)11(444), 10-12. 
- ZOVKIĆ, Mato, Parabola o osramoćenom gospodaru i nepravednom upravitelju (Prvi dio), u: Crkva na kamenu 39(2018)11(456), $10-12$.

- ZOVKIĆ, Mato, Parabola o osramoćenom gospodaru i nepravednom upravitelju (Drugidio), u: Crkva na kamenu 39(2018) 12(457), 10-13.

- ZOVKIĆ, Mato, Parabola o povjerenim srebrnjacima (Prvi dio), u: Crkva na kamenu 38 (2017) 4 (437), 9-12.

- ZOVKIĆ, Mato, Parabola o povjerenim srebrnjacima (Drugi dio), u: Crkva na kamenu 38 (2017) 5 (438), 10-13.

- ZOVKIĆ, Mato, Parabola o povjerenom novcu (talentu) (Prvi dio), u: Crkva na kamenu 38 (2017) 2 (435), 10-13.

- ZOVKIĆ, Mato, Parabola o povjerenom novcu (talentu (Drugi dio), u: Crkva na kamenu 38 (2017) 3 (436), 9-12.

- ZOVKIĆ, Mato, Parabola o pronađenom blagu i otkrivenom biseru (Prvi dio), u: Crkva na kamenu 38 (2017) 12 (445), 10-12.

- ZOVKIĆ, Mato, Parabola o pronađenom blagu i otkrivenom biseru (Drugi dio), u: Crkva na kamenu 39 (2018) 1 (446), 10-12.

- ZOVKIĆ, Mato, Parabola o razvrstavanju ulovljenih riba, u: Crkva na kamenu 39 (2018) 2 (447), 10-13.

- ZOVKIĆ, Mato, Parabola o samodostatnom bogatašu i bolesnom siromahu (Prvi dio), u: Crkva na kamenu 39 (2018) 8-9 (453454), 10-12.

- ZOVKIĆ, Mato, Parabola o samodostatnom bogatašu i bolesnom siromahu (Drugi dio), u: Crkva na kamenu 39 (2018) 10 (455), 10- 12.

- ZOVKIĆ, Mato, Parabola o sjemenu zasijanom u četiri vrste tla (Prvi dio), u: Crkva na kamenu 37 (2016) 1 (422), 9-12.

- ZOVKIĆ, Mato, Parabola o sjemenu zasijanom u četiri vrste tla (Drugi dio), u: Crkva na kamenu 37 (2016) 2 (423), 9-12.

- ZOVKIĆ, Mato, Parabola o upornoj udovici (Prvi dio), u: Crkva na kamenu 39 (2018) 6 (451), 10-12.

- ZOVKIĆ, Mato, Parabola o upornoj udovici (Drugi dio), u: Crkva na kamenu 39 (2018) 7 (452), 10-12.

- ZOVKIĆ, Mato, Parabola o vinogradarima ubojicama (Prvi dio), u: Crkva na kamenu 37 (2017) 12 (433), 9-12.

- ZOVKIĆ, Mato, Parabola o vinogradarima ubojicama (Drugi dio), u: Crkva na kamenu 38 (2017) 1 (434), 9-13.

- ZOVKIĆ, Mato, Parabola o zasijanu sjemenu koje nezaustavljivo raste, u: Crkva na kamenu 38 (2017) 8-9 (441-442), 9-12. 
- ZOVKIĆ, Mato, Povratak Svete Obitelji radi Isusova odrastanja u Galileji, u: Katolički tjednik 15 (39) (2016) 51-52, 18-20.

- ZOVKIĆ, Mato, Prispodobe o novoj zakrpi i novom vinu (Prvi dio), u: Crkva na kamenu 37 (2016) 10 (431), 9-11.

- ZOVKIĆ, Mato, Prispodobe o novoj zakrpi i novom vinu (Drugi dio), u: Crkva na kamenu 37 (2016) 11 (432), 9-12.

- ZOVKIĆ, Mato, Slika o pastiru koji razlučuje jarce od ovaca u Isusovu eshatološkom govoru (Prvi dio), u: Crkva na kamenu 37 (2016) 7 (428), 10-14.

- ZOVKIĆ, Mato, Slika o pastiru koji razlučuje jarce od ovaca u Isusovu eshatološkom govoru (Drugi dio), u: Crkva na kamenu 37 (2016) 8-9 (429-430), 9-12.

- ZOVKIĆ, Mato, Slika o pastiru koji razlučuje ovce od jaraca (Mt 25,31-46), u: Biblija danas 15 (22) (2017) 3, 15-23.

- ŽUPARIĆ, Drago, Herodov kvasac: paradigma tiranije u liku Heroda Velikog i Heroda Antipe, u: Katolički tjednik 16 (40) (2017)1, 19-21.

- ŽUPARIĆ, Drago, Poniznost: kršćanska vrlina, u: Katolički tjednik 16 (40) (2017) 51-52, 36-37.

NEW TESTAMENT BIBLICAL BIBLIOGRAPHY (2016-2018)

\section{Summary}

The article is the second part, a continuation of the article which has already been published in the "Crkva u Svijetu", and which refers to the Old Testament part of the biblical bibliography in Croatian language. A total of seventeen (17) journals, published in the Republic of Croatia and Bosnia and Herzegovina, have been dealt with. The article is divided into seven (7) parts: 1. Editions of Holy Scripture (1 x); 2. six (6) monographs; 3. two (2) doctoral dissertations; 4. other: one (1) writing; 5. twenty-nine (29) contributions in collections by eighteen (18) authors; 6 . contributions from professional journals of a scientific nature (A1, A2 ...) - a total of thirty-seven (37) contributions by twenty-four (24) authors, and 7. contributions from "weekly, monthly, Bible Today" - a total of one hundred and sixteen contributions) by eleven (11) authors. The wish and intention of the author of the article is to be of help to all colle- 
agues, but also to all students and lovers of the Word of God, who deal with the Bible and for whom this article can make it easier to find the title of a certain topic.

Key words: Bible, New Testament, biblical bibliography, Croatian biblical bibliography, New Testament Croatian biblical bibliography 